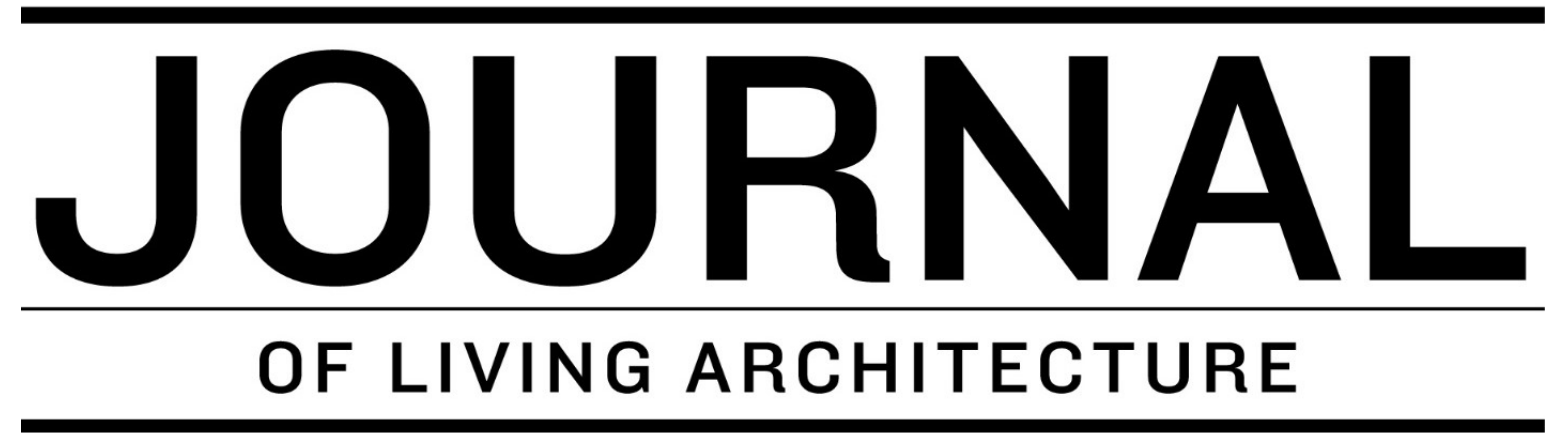

A GREEN ROOFS FOR HEALTHY CITIES PUBLICATION

\title{
Stormwater calculation application for low impact development in the conceptual design phase of urban site development
}

\author{
Feng Wu ${ }^{1}$, Jericho Bankston ${ }^{1}$, Daniel Roehr ${ }^{1,}$ *, Feiyu Wei ${ }^{2}$ \\ ${ }^{1}$ greenskins lab, School of Architecture and Landscape Architecture, University of British \\ Columbia, Canada \\ ${ }^{2}$ Department of Architecture and Urban Design, Beijing University of Civil Engineering and \\ Architecture, China \\ *droehr@sala.ubc.ca
}

\begin{abstract}
There are many existing Low Impact Development (LID) applications available to calculate stormwater runoff volume, but they often fail to address LID systems in the initial design stages. To address this problem a LID application was developed for international use that supports designers considering how to reduce stormwater runoff through LID strategies. The result is an iterative design process that allows designers to visualize results. This helps users make informed decisions when it comes to stormwater management practices that are based on a combination of readily available local climate data and existing site conditions to create preliminary runoff results.
\end{abstract}

$\underline{\text { Holistic Stormwater Runoff Management Application }}$

Key words: Low Impact Development (LID), Green Buildings, Stormwater Management, Urban Planning, Conceptual Design 


\section{INTRODUCTION}

One prominent global problem of climate change is extreme rainfall, leading to urban disasters including flooding and waterlogging (Asiedu, 2020; Chang and Franczyk, 2008; Crnogorac and Rajcevic, 2018; Gilland, 2002). As a result of this increase in extreme rain events the implementation of Low Impact Development (LID) as a system for urban comprehensive rainwater management is being used more frequently in urban development and building construction and renovation (Akinyemi, 2008; Sharma et al., 2019). In urban areas the hydrological cycle first needs to be evaluated at the building and site level in order to avoid flooding (Prickett and Bicknell 2010).

When developing a new or existing site, designers often do not consider the integration of LID on the site which can lead to challenges as the design process moves forward (Allen et al., 2010). This results in the LID strategy being integrated with the site as an afterthought to the initial planning and design of the building and site amenities. Not only does this deviate from the original intention of LID development but also reduces the maximum potential for LID systems.

This paper presents a solution to the problem of planning LID systems as an afterthought by creating an easy-to-use spreadsheet design application for designers, developers, municipalities, and those interested in sustainable site design practices. The method was developed to rely on local airport and weather station data and can be applied at the initial design stages to assess the amount of precipitation that will accumulate onsite and to help determine what combination of LID strategies can be used to reduce stormwater runoff. This strategy will enable designers to quickly calculate and estimate the surface area required to manage cumulative stormwater runoff for detailed stormwater and civil design later. The intention is to integrate sustainable stormwater management systems into new and existing design projects, and actively promote the construction of water-wise urban developments. This practice is becoming more common due to new sustainability frameworks such as Leadership in Energy and Environmental Design (LEED 2019) and Living Building Challenge (“Living Building Challenge,” 2019).

\section{Theory and background}

In 1999 the Environmental Protection Agency (EPA) released the "Low-Impact Development Design Strategies: An Integrated Design Approach" and "Low-Impact Development Hydrologic Analysis" to promote the nationwide use of LID (Li et al., 2015; McMahon et al., 2018). The core objective of LID is to protect and restore natural hydrological characteristics by mimicking the hydrological process before site development as much as possible, thereby mitigating the impact of urban development and construction on the natural hydrological process (Chang, 2010; Cheng et al., 2001). In 2012 the EPA issued a terminology specifically for LID which explains that LID is a comprehensive planning and design method, a holistic practice, different from traditional stormwater management practices ("Terminology of Low Impact Development,” 2012). This holistic approach was developed in order to achieve 
comprehensive control of stormwater runoff and runoff pollution at the source as much as feasible.

LID promotes an engineered simulation of natural conditions (Guillette, 2016). By using smallscale, decentralized, ecological treatment technologies at the source, the hydrological characteristics of the area after development are similar to conditions before development (Eckart et al., 2017; Li et al., 2018). LID strategies are particularly suitable for site-level planning and design to control runoff and pollution caused by storms (Guillette, 2016; Sharma et al., 2019). This technology combines engineering and design solutions to simulate natural processes for infiltration, filtration, and evaporation (Olorunkiya et al., 2012). The primary purpose of LID is to retain, delay or reuse stormwater where it is generated while traditional stormwater management allows stormwater from multiple sites to converge increasing the chances of flooding and damage due to stormwater runoff (Liptan and Santen, 2019).

LID include permeable pavement, green roofs, biological retention, swamps, permeable wells and trenches, permeable wetlands and rainwater harvesting (Hunt et al., 2010; Rodak et al., 2019). Often an under-utilized surface, the green roof of a building combined with the surrounding site can serve a critical role in stormwater collection and retention (Roehr and Kong, 2010). By using green roofs, green building facades and green streets, stormwater runoff can be reduced as well as building energy consumption and carbon dioxide emissions (Roehr et al., 2008).

However, how to allocate the areas for LID and building structures in a limited site requires the designer to control the site's overall LID by planning for it at the initial stage of the design. In order to more effectively determine the necessary LID measures during the construction document phase, the designer needs to understand the amount of stormwater generated at the site during the initial design phase, so they can effectively choose between the different LID systems to later implement.

\section{Stormwater Calculation Methods}

We have compiled the following methods to calculate stormwater runoff of implemented LID methods.

Storm Water Management Model (SWMM) and National Stormwater Calculator $(S W C)(E P A)$

Developed by the US Environmental Protection Agency (EPA), the SWMM model is a dynamic simulation model of runoff (Rossman et al., 2004; Storm Water, 2020). It is primarily used for surface runoff, pipelines, and pollutant transmission calculations (Storm Water, 2017). It can continuously and completely simulate the process of rainfall runoff and pollutant generation and transportation (Hluštík et al., 2016). The calculation process of the SWMM model requires detailed surface and drainage system information and can require long calculation times (Storm Water, 2017). In the initial stage of design, it is difficult to fully obtain 
off-site related information and calculations need to be quickly and easily obtained. Therefore, this method is not suitable for the site design stage. The EPA does have a simplified version based off SWMM, named National Stormwater Calculator (EPA National, 2020), however the use is limited to the United States and results are based on percentages of area with predetermined LID control methods and limits user's ability to input their own curve number values.

\section{Rational Method}

The Rational Method is used to estimate the design flow of a small watershed (Pennington 2012). It is mainly used to predict peak discharge and connect the runoff generation of the developed watershed with the average rainfall intensity of a specific time length (concentration time) and the drainage area of the watershed, including storm runoff in two-, five- and ten-year storm events (Chin 2019; Hayes and Young, 2006; Wang and Wang 2018). However, the site LID design should not only consider extreme rainfall events, but also take into account annual rainfall patterns. If extreme storm events alone are used as the basis of design for LID planning, the systems will inevitably be oversized, resulting in waste of materials and surface space during the construction process.

\section{Technical Release 55 - Curve Number Method (TR-55 CN Method)}

The TR-55 CN Method was developed by Natural Resources Conservation Service (NRCS), Soil Resources Protection Bureau for the calculation of small urban watershed runoff (Ports, 2001). It uses the SCS runoff curve number infiltration curve to calculate runoff and can calculate the runoff depth of different surface materials (McCormick and Eshleman, 2011; Mishra and Singh, 2003; USDA, 1986). The runoff curve number, also called a curve number or simply $\mathrm{CN}$, is an empirical parameter used in hydrology for predicting direct runoff or infiltration from rainfall excess and was developed from an empirical analysis of runoff from small catchments and hillslope plots monitored by the United States Department of Agriculture (USDA) (USDA, 1986). It is widely used in landscape ecology, urban design and other practices and is an efficient method for determining the approximate amount of direct runoff from a rainfall event in a particular area. This method has the advantages of being user-friendly and utilizes a short calculation process, it is for these reasons that the calculation method proposed in this paper is based on the TR-55 CN Method.

\section{Existing Calculation Comparisons}

In addition to the methods outlined above the authors compared three existing LID stormwater management applications including the EPA's National Stormwater Calculator ("EPA National Stormwater Calculator,", 2019), Portland Oregon's Stormwater Presumptive Approach Calculation ("Stormwater Presumptive Approach Calculator", 2020) and the Green Values Stormwater Management Calculator ("Stormwater Management Calculator", 2020). In Table 1 below the authors compared the above methods qualitatively for their ease of use and effectiveness for assisting designers in planning stormwater management systems. 
Existing calculation methods have limitations when used alone and are not appropriate for the initial design stages of planning and developing a building and its affiliated sites. There are many additional applications offered by municipalities, cities and various international governments that address LID at site and urban scales as well as applications that address green roof design for delayed stormwater runoff and evapotranspiration rates. However, these applications can be hard to find, can involve fees to access or need in-depth technical knowledge to use. Applications reviewed were easily accessible online, free to access and use, developed in English, and could be used for low impact development and/or green roof stormwater management.

Table 1 LID qualitative calculation comparison.

\begin{tabular}{|c|c|c|c|c|c|c|c|}
\hline \multicolumn{2}{|c|}{$\begin{array}{l}\text { REVIEWED CALCULATORS } \\
\& \text { METHODS }\end{array}$} & $\begin{array}{l}\text { SWMM } \\
\text { (SWM } \\
\text { M, } \\
2020)\end{array}$ & $\begin{array}{l}\text { EPA } \\
\text { SWC } \\
\text { (EPA } \\
\text { "Natio } \\
\text { nal...", } \\
2019 \text { ) }\end{array}$ & $\begin{array}{l}\text { Rational } \\
\text { Method } \\
\text { (Pate, } \\
\text { 2019) }\end{array}$ & $\begin{array}{l}\text { TR-55 CN } \\
\text { Method } \\
\text { (USDA, } \\
1986 \text { ) }\end{array}$ & $\begin{array}{l}\text { Stormwater } \\
\text { Presumptive } \\
\text { Approach } \\
\text { Calculator } \\
\text { ("Stormwate } \\
\text { r } \\
\text { Presumptive } \\
\text {..", 2020) }\end{array}$ & $\begin{array}{l}\text { Green } \\
\text { Values } \\
\text { Stormwater } \\
\text { Management } \\
\text { Calculator } \\
\text { ("Stormwate } \\
\text { r } \\
\text { Management } \\
\text {...", 2020) }\end{array}$ \\
\hline \multicolumn{8}{|c|}{$\begin{array}{r}\text { FACTORS OF } \\
\text { CONSIDERATION }\end{array}$} \\
\hline \multicolumn{2}{|c|}{ Fast Calculation } & & & $\sqrt{ }$ & & & $\sqrt{ }$ \\
\hline \multicolumn{2}{|c|}{ Accurate Calculation } & $\sqrt{ }$ & & & & & $\sqrt{ }$ \\
\hline \multicolumn{2}{|c|}{ Data is easily accessible } & & $\sqrt{ }$ & & $\sqrt{ }$ & & $\sqrt{ }$ \\
\hline \multicolumn{2}{|c|}{ Data required is easy to obtain } & & $\sqrt{ }$ & & $\sqrt{ }$ & $\sqrt{ }$ & \\
\hline & Ease of use & & $\sqrt{ }$ & & $\sqrt{ }$ & $\sqrt{ }$ & \\
\hline \multicolumn{2}{|c|}{$\begin{array}{l}\text { Suitable for various } \\
\text { development scales }\end{array}$} & & $\sqrt{ }$ & $\sqrt{ }$ & $\sqrt{ }$ & $\sqrt{ }$ & $\sqrt{ }$ \\
\hline \multirow{4}{*}{$\begin{array}{l}\text { Land types } \\
\text { included in } \\
\text { the site } \\
\text { design }\end{array}$} & Pavement & $\sqrt{ }$ & $\sqrt{ }$ & $\sqrt{ }$ & $\sqrt{ }$ & & $\sqrt{ }$ \\
\hline & Green roof & $\sqrt{ }$ & & & & & $\sqrt{ }$ \\
\hline & $\begin{array}{r}\text { Attached green } \\
\text { space } \\
\end{array}$ & $\sqrt{ }$ & $\sqrt{ }$ & & $\sqrt{ }$ & & $\sqrt{ }$ \\
\hline & $\begin{array}{l}\text { Adjustable CN } \\
\text { and Kc Values }\end{array}$ & & & & & & $\sqrt{ }$ \\
\hline
\end{tabular}

These calculation methods can be complicated to use and are often only accessible by knowledgeable professionals such as hydrological engineers, this is not convenient for architectural designers when preparing initial design concepts. Additionally, the accuracy of the above-mentioned calculation methods is not precise enough and can result in large deviations between the calculated area needed for LID and the actual area needed. Some methods calculate accurately but require detailed parameters and data which in many regions around the world is difficult to obtain.

\section{HOLISTIC MODEL GOALS}


When considering the site characteristics which include structures and post construction landscaping, the designers need to identify project requirements to be addressed in the initial design stage. The authors believe that a calculation method should be utilized to help integrate holistic LID system design needs into the project and site at earlier project development stages to understand stormwater management needs and better incorporate LID systems. The following requirements for an application were identified:

- A stormwater management method suitable for small and medium-sized sites, with a focus on urban regions.

- Data needed should be easily obtained. Operation of the application must be straightforward and practical, and results should be comprehensive, clear and visualized.

- The application should use plain LID terminology to reduce misunderstandings.

- The calculation of this method needs to include the coefficients for calculating the runoff of impervious surfaces, LID systems, green roofs, and other surface types.

- The results should reflect monthly and annual stormwater runoff to compare the differences between rainy and dry seasons. The designer needs to consider both stormwater runoff combined with dry season irrigation requirements. If the calculation is based only on extreme rainfall events, it may lead to an oversized LID system, which could require more irrigation and maintenance issues.

- The calculation method needs to be able to dynamically reflect the runoff changes of the plan in an intuitive way according to the adjustment of the design concept.

- It must be convenient for designers to evaluate different design schemes and provide reference for designers to adjust different LID strategies, while maintaining a reference basis for communication between users, developers, and designers.

The application was designed to be open-ended. Goals are set by the user, whether they are ambitious and look to achieve $100 \%$ runoff reduction, are specific to municipality and regional requirements or are seeking to achieve an existing rating system requirement for certification. It was done this way because the authors understand each project comes with a unique set of circumstances, and not all sites will allow for the same infrastructure or have the same needs. This gives users the flexibility to focus on the systems they can implement with the opportunity to explore as many combinations as possible.

While the application discussed below was developed to focus on holistic LID planning and design, it provides some other less explored benefits. It can be helpful in defining project scope and LID programming requirements and the resulting design has project areas and utilized systems built in which can be used to estimate LID project costs and serve as a basis of design.

\section{CALCULATION PROCESS}

\section{Overall Calculation Idea}


The LID application in this paper is broken down into two parts as seen in Figure 1 below. Part 1 is for the calculation of daily, monthly, and annual results, while part 2 is for calculating runoff for different design storm events.

The first part is based on daily precipitation, temperature and site-specific data that is used to calculate the daily runoff. The ground runoff is calculated with the TR-55 method. On the roof, since the roof surface is impervious, water cannot infiltrate as it does at ground level, but ends up in the roof drainage system as part of the runoff. Therefore, rainwater falls on the roof as if it were falling on a traditional impervious surface, which can be calculated by the TR-55 method. Though some research uses an experimentally derived curve number of 86 for green roofs (Carter and Jackson 2006), TR-55 which includes soil infiltration in its calculation was not intended for use on green roofs where there is no infiltration. In place of TR-55 the HargreavesSamani Method (Samani, 2000) is used to calculate evapotranspiration (Roehr and Kong 2010). Once the daily net flows are calculated, the monthly and annual net flows can be derived through summation. The monthly calculation results show the differences between the wet and dry seasons, indicate total monthly runoff, and potentially required irrigation volumes needed by green roofs during the dry season. While the annual calculation results show total runoff of the site in the given year as well as total yearly runoff and any reductions in runoff as a result of site LID strategies.

The second portion of the application is based on storm event data which uses historical storm events to predict the frequency certain amounts of intense rainfall will occur in a given period of time. This allows for the application to calculate the maximum rainfall that the site can withstand based on design storm events with 2-, 5- and 10-year return periods.

The LID application provides both sets of results as a reference for designers, this is different from other applications that focus only on extreme rainfall in the early stages of design. Those methods are likely to make LID facilities, such as green roofs, rain gardens and retention ponds too large and thus increase irrigation problems and the cost of maintenance in the future.

These two sets of results help assist designers as they consider site LID strategies in the initial stage of design. After the designer chooses the LID design measures, such as the area of the green roof and the design form of the rain garden, the calculation is then used to verify the effectiveness of the proposed LID system. After inputting the various areas of the design into the LID application to get the stormwater runoff volume, the designer can then evaluate the impact any LID design has on stormwater runoff and is able to modify the plan for optimization or site needs. This helps the design by allowing them to weigh specific project needs, balance the need of stormwater runoff reduction and the cost and maintenance required by different design strategies. With the help of the LID application, designers will be able to come out with educated LID strategies and planning decisions. 


\section{LID Calculation}

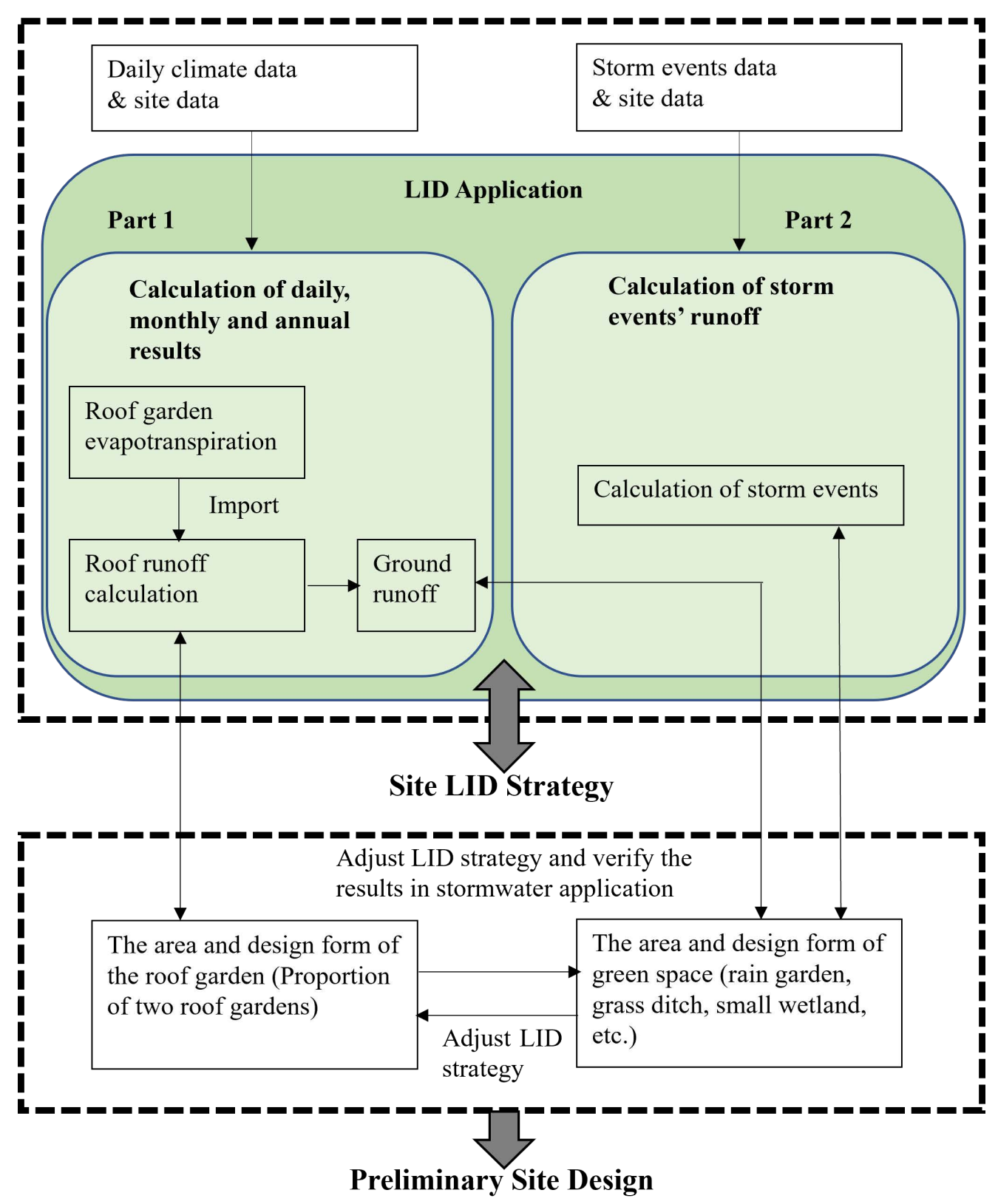

Figure 1 Calculation process framework. Part 1: Monthly and annual runoff evaluation for implemented LID systems. Part 2: Design storm event for 2-, 5- and 10-year design storms.

\section{Basic Calculation Methods}

The two basic calculation methods include TR-55 CN Method and HS Method.

\section{Method A: TR-55 CN Method}

In the TR-55 CN method, the calculation formula for runoff is as follows: 
[eq. 1-1] When $\mathrm{P}+2-200 / \mathrm{CN}>0$, then $\mathrm{Q}=(\mathrm{P}+2-200 / \mathrm{CN})^{2} /(\mathrm{P}-8+800 / \mathrm{CN})$

When $\mathrm{P}+2-200 / \mathrm{CN} \leq 0$, then $\mathrm{Q}=0$

(Note: The unit of the equation is inches.)

Parameters:

1. Q: surface runoff depth per unit area (in)

2. P: daily precipitation depth (in) (including rain, snow, etc.)

Note: Users need to supply precipitation data which can be obtained from local airports and public weather stations.

3. CN: Curve Number, refer to TR-55 document.

Method B: Hargreaves Samani (HS) Method

The HS Method estimates solar radiation based on climate data to calculate crop evapotranspiration (ET). By calculating ET, plant stormwater consumption is factored into the overall LID infrastructure which reduces overall stormwater runoff and gives users an understanding of irrigation requirements of the LID system during dry seasons. In the HS method, the calculation formula for runoff is as follows:

[eq. 2-1] $\mathrm{ET}_{0}=0.408\left[0.0023\left(\mathrm{~T}_{\text {mean }}+17.8\right)\left(\mathrm{T}_{\max }-\mathrm{T}_{\min }\right) * 0.5 * \mathrm{Ra}\right]($ Samani, 2000)

[eq. 2-2] $\mathrm{ET}_{\mathrm{c}}=\mathrm{ET}_{0} * \mathrm{Kc}$

Parameters:

1. $\mathrm{ET}_{0}$ : evapotranspiration $(\mathrm{mm})$

4. $\mathrm{T}_{\text {mean }}$ : daily mean temperature $=\left(\mathrm{T}_{\max }-\mathrm{T}_{\min }\right) / 2$

5. $\mathrm{T}_{\max }$ : daily maximum temperature $\left({ }^{\circ} \mathrm{C}\right)$

6. $\mathrm{T}_{\text {min }}$ : daily minimum temperature $\left({ }^{\circ} \mathrm{C}\right)$

Note: Users need to supply maximum and minimum temperature data which can be obtained from local airports and public weather stations.

7. Ra: external radiation (Snyder and Eching 2002)

8. $\mathrm{ET}_{\mathrm{c}}$ : water requirement $(\mathrm{mm})$

9. ET0: evapotranspiration ( $\mathrm{mm}$ )

10. Kc: Crop Coefficient, it is the ratio of plant water requirement to evapotranspiration.

Note:

- Kc value reference:

○ Extensive Roof - $\mathrm{Kc}=0.3$

○ Intensive Roof - $\mathrm{Kc}=0.6$

\section{Calculation Process for Daily Runoff and Relative Results}

\section{Calculating Roof Runoff}

As the runoff from the roof will eventually be collected into the LID systems on the ground, there is a need to calculate the roof runoff at the beginning. In the model of the LID application, the roof includes the grey roof (i.e., impervious hardscape) and green roof systems including 
intensive and extensive types. In general, the bottom of the green roof assembly is impervious. It means that the water of the green roof media cannot infiltrate into the ground, which is different from green space at grade. Therefore, we use the HS method to calculate the water retention of the green roof and the rest of the runoff from the impervious roof assembly is calculated by the TR-55 CN method. The revised water balance equation (Roehr and Kong, 2010) is shown as below:

[eq. 3-1] Runoff_roof $=$ Q_roof * A_roof - ETc_Eroof * A_Eroof - ETc_Iroof * A_Iroof + $\sum \mathrm{I}$

Parameters:

1. Runoff_roof

2. Q_roof

3. A roof

4. ETc Eroof

5. A Eroof

6. ETc Iroof

7. A Iroof

8. $\sum \overline{\mathrm{I}}$ $=$ total runoff of the roof in a day $\left(\mathrm{m}^{3}\right)$

$=$ surface runoff depth (Use $\mathrm{CN}=98$ to calculate Q_roof as the base of the roof is an impermeable surface) (m)

$=$ total area of the roof $\left(\mathrm{m}^{2}\right)$

$=$ water requirement of extensive roof $(\mathrm{m})$

$=$ area of extensive roof $\left(\mathrm{m}^{2}\right)$

$=$ water requirement of intensive roof $(\mathrm{mm})$

$=$ area of intensive roof $\left(\mathrm{m}^{2}\right)$

$=$ sum of irrigation volume $\left(\mathrm{m}^{3}\right)$

Note:

When Runoff_roof $>0$, there is runoff, When Runoff_roof $=0$, there is no runoff.

When Runoff_roof $<0$, there is no runoff, and plants may need to be irrigated theoretically, Practical irrigation needs will be based on plant species and climate.

\section{Calculating Grade Runoff}

The runoff from the roof area will be collected by the LID system at grade, which will be calculated in this second step. In the model of the LID application, the ground area includes additional systems and LID systems. The additional systems contain impermeable paving, permeable paving and lawns. The LID system contains different types of LID areas. Different types of LID areas form a whole to receive runoff from the additional systems and from the roof. The current application can support a maximum of four types of different LID areas.

All the additional system runoff and the roof runoff will eventually flow into the green space, until the green space can no longer absorb additional runoff. As a result, the leftover runoff from the green space is the total runoff of the day on the field. The runoff from other areas to the LID system will spread over the surface as sheet flow. Based on the TR-55 method, the composite $\mathrm{CN}$ value will need to be used in the calculation of the runoff of sheet flow like in the entire LID system here. The composite CN value of the LID system is equal to the weighted average of each LID space. (USDA 1986) The equation is as shown in [eq. 3-5].

[eq. 3-2] Runoff_nonLID $=\mathrm{Q} \_I P * A \_I P+Q \_P P * A \_P P+Q \_L A * A \_L A$

[eq. 3-3] A_LID $=$ A_LID1 + A_LID $2+$ A_LID3 + A_LID4

[eq. 3-4] P_LID $=$ (Runoff_roof + Runoff_nonLID) $/$ A_LID $+\mathrm{P}$

J. of Living Arch 8(1)

Feature 50 
[eq. 3-5] CN_LID $=\left(C N \_L I D 1 *\right.$ A_LID $1+$ CN_LID2 $*$ A_LID2 + CN_LID3 $*$ A_LID3 + CN_LID4 $* \bar{A}$ _LID4) / A_LID

[eq. 3-6] Runoff_LID $=$ Q_LID * A_LID

\section{Parameters}

1. Runoff_nonLID

2. Q_IP \& A_IP

3. Q_PP \& A_PP

4. Q_LA \& A_LA

5. A LID

6. A_LID $1 / 2 / 3 / 4$

7. P_LID

8. $\mathrm{P}$

9. CN LID

10. CN_LID1/2/3/4

11. Runoff_LID

12. Q_LID
$=$ total runoff of the non-LID system $\left(\mathrm{m}^{3}\right)$

$=$ runoff depth $\&$ area of impermeable paving area $\left(\mathrm{m} \& \mathrm{~m}^{2}\right)$

$=$ runoff depth $\&$ area of permeable paving area $\left(\mathrm{m} \& \mathrm{~m}^{2}\right)$

$=$ runoff depth $\&$ area of lawn area $\left(\mathrm{m} \& \mathrm{~m}^{2}\right)$

$=$ total area of LID system $\left(\mathrm{m}^{2}\right)$

$=$ area of LID - type $1 / 2 / 3 / 4\left(\mathrm{~m}^{2}\right)$

$=$ precipitation depth of LID system (Runoff from roof and non-LID system are regarded as part of the precipitation for the LID system) (m)

$=$ daily precipitation depth $(\mathrm{m})$

$=$ composite $\mathrm{CN}$ of LID system

$=\mathrm{CN}$ of LID - type $1 / 2 / 3 / 4$

$=$ total runoff the LID system, which is the runoff of the entire site as well $\left(\mathrm{m}^{3}\right)$

$=$ runoff depth of LID system (Using P_LID and CN_LID to calculate Q_LID) (m)

\section{Calculating Relative Monthly Results}

In the application, the Result Section 2 (see Figure 4) is monthly calculation results. Most of the monthly results are the sum of the data of the relevant month, including precipitation of the whole site, precipitation of roof, precipitation of ground area, roof evapotranspiration, roof runoff, and final site runoff volume. Monthly green roof irrigation volume is calculated by the sum of Runoff_roof in [eq. 3-1] as below:

[eq. 3-7] Sum_runoff_roof $=$ Runoff_roof (day 1) + Runoff_roof (day 2) + Runoff_roof (day $3)+\ldots \ldots+$ Runoff_roof (last day of the month)

If Sum_runoff_roof $=0$ or Sum_runoff_roof $>0$, then Irrigation_roof $=0$,

If Sum_runoff_roof $<0$, then Irrigation_roof $=-1 *$ Sum_runoff_roof

\section{Parameters}

1. Sum_runoff_roof $=$ sum of the value of runoff_roof in a month $\left(\mathrm{m}^{3}\right)$

2. Runoff_roof $=$ total runoff of the roof in a day $\left(\mathrm{m}^{3}\right)$

3. Irrigation_roof $=$ potential monthly irrigation volume of green roof $\left(\mathrm{m}^{3}\right)$

Monthly runoff mitigation is the sum of daily runoff mitigation volume. Runoff mitigation volume means the runoff volume mitigated by any site LID design including green roofs, permeable paving, lawn or LID system compared to just using impermeable paving for the whole site. Its calculation process is as below:

[eq. 3-8] Runoff_mitigation $=$ Q_IP * (A_roof + A_nonLID + A_LID) - Runoff_LID 
Parameters

1. Runoff_mitigation = daily runoff mitigation volume $\left(\mathrm{m}^{3}\right)$

2. Q_IP = runoff depth of impermeable paving $(\mathrm{m})$. Its $\mathrm{CN}$ is 98

3. A roof = total area of the roof $\left(\mathrm{m}^{2}\right)$

4. A_nonLID = total area of the non-LID $\operatorname{system}\left(\mathrm{m}^{2}\right)$

5. A_LID = total area of the LID system $\left(\mathrm{m}^{2}\right)$

6. Runoff_LID = total runoff the LID system, which is the runoff of the entire site as well $\left(\mathrm{m}^{3}\right)$

\section{Calculating Relative Annual Results}

In the application, the Result Section 3 (see Figure 4) are the holistic calculation results in a year. Total precipitation is the sum of daily precipitation volume. Roof catchment or ground catchment is the sum of relevant precipitation volume caught by roof or ground areas.

Remaining runoff means the total runoff volume of the site in a year. It is the sum of all Runoff_LID in [eq. 3-6].

Runoff mitigation percentage refers to the percentage of runoff volume mitigated by any site LID design including green roofs, permeable paving, lawns or LID system compared to just using impermeable paving for the whole site. It can be calculated by the data of monthly runoff mitigation.

\section{Calculation Process for Storm Events}

Before the calculation starts, it is necessary to get access to the local climate database to find the 24-hour precipitation value of the local events of 2/5/10 years. Data for the United States can be found on NOAA's National Weather Service Toolkit Climate Site (NOAA, 2021). International design storm data can be found through local city jurisdiction databases as well as through government organizations. In the application, the Result Section 1 (see Figure 4) are the storm event calculation results. Storm event calculation includes the calculation of 2, 5, and 10 year events. The calculation method is based on the method of calculating runoff and potential retention by the SCS-CN method. In addition, the amount of retention by the growing media of green roofs is included as well.

[eq. 4-1] Runoff_x-year $=$ Runoff_roof + Runoff_ground

[eq. 4-2] Runoff_roof $=\mathrm{Q}$ roof $*$ A_roof - RV_Iroof - RV_Eroof

[eq. 4-3] RV_Iroof $=$ A_Iroof $* S D$ Iroof $*$ RVP_Iroof

[eq. 4-4] RV_Eroof $=\mathrm{A}_{-}$Eroof $* \mathrm{SD} \overline{-}$ Eroof $* \mathrm{RVP}$ _Eroof

[eq. 4-5] Runoff_ground $=\mathrm{Q} \_g l * A$ A_gl + P_x-year * A_LID - (S_LID + Ia_LID)* A_LID [eq. 4-6] Ia_LID $=0.2 *$ S_LID (USDA 1986)

The final calculated result is the runoff of the site during extreme storm events. In the calculation method ' $\mathrm{x}$ ' can be 2-, 5- or 10-year event, the calculation process is as follows: 


\section{Parameters}

1. Runoff $x$-year

2. Runoff roof

3. Runoff_ground

4. Q_roof

5. A roof

6. $\mathrm{RV}$ Iroof

7. RV_Eroof

8. A Iroof

9. $\mathrm{SD}$ - Iroof

10. RVP Iroof

11. A Eroof

12. SD_Eroof

13. RVP_Eroof

14. Q_gl

15. A gl

16. $\mathrm{P} \mathrm{x}$-year

17. A LID

18. S_LID

19. Ia_LID
$=$ total runoff of the site for a $\mathrm{x}$ year event $\left(\mathrm{m}^{3}\right)$

$=$ total runoff of the roof $\left(\mathrm{m}^{3}\right)$

$=$ total runoff of the ground $\left(\mathrm{m}^{3}\right)$

$=$ runoff depth of the roof $(\mathrm{m})$

$=$ total area of the roof $\left(\mathrm{m}^{2}\right)$

$=$ Retention volume of intensive roof $\left(\mathrm{m}^{3}\right)$

$=$ Retention volume of extensive roof $\left(\mathrm{m}^{3}\right)$

$=$ Area of intensive roof $\left(\mathrm{m}^{2}\right)$

$=$ Soil Depth of Intensive roof $(\mathrm{m})$. Soil depth of intensive roof. The commonly used depth is $450 \mathrm{~mm}$, which can be used for shrub planting, or $600 \mathrm{~mm}$, which can be used for tree planting. Here the author assumes the depth to be $500 \mathrm{~mm}$ in average.

$=$ retention volume percentage of intensive roof. The value is $23 \%$. See Note below for explanation.

$=$ area of extensive roof $\left(\mathrm{m}^{2}\right)$

$=$ soil depth of extensive roof $(\mathrm{m})$. The commonly used depth is $150 \mathrm{~mm}$, which is suitable for ground covers or Sedum plants.

$=$ retention volume percentage of extensive roof. The value is $21 \%$. See Note below for explanation.

$=$ runoff depth of ground land $(\mathrm{m})$

$=$ area of ground land $\left(\mathrm{m}^{2}\right)$

$=$ precipitation depth of the $\mathrm{x}$ year event $(\mathrm{m})$

$=$ area of LID system $\left(\mathrm{m}^{2}\right)$

$=$ potential maximum retention of LID area after runoff begins. S_LID $=1000 / \mathrm{CN}-10$ (Unit: inch) (USDA 1986), so S LID $=25.4 / \mathrm{CN}-0.254$ (Unit: $\mathrm{m}$ )

$=$ Initial abstraction of LID area (m)

Notes:

- If Runoff_roof $>0$, which means there is runoff from the roof area, then Runoff_x-year will be calculated as shown above in [eq. 3-1]. Otherwise, if Runoff_roof $<=0$, which means there is no runoff from the roof area, the number of Runoff_roof cannot be added up to the total runoff, so Runoff_x-year=runoff_ground.

- There is no average number for Plant Available Water (PAW) however most of the PAW amounts are between 20\% - 30\% (Roehr and Fassman-Beck 2015). From a conservative point of view, the German Landscape Development and Landscaping Research Society (FLL 2018) is used as the standard and uses the average of its standard range as the retention percentage in the LID application. Therefore, the retention percentages used are $23 \%$ for intensive roofs and $21 \%$ for extensive roofs. Further argument can be seen in the discussion section.

Based on the six formulas above, the following formula can be obtained: 
[eq. 4-7]

if Runoff_roof $>0$, then:

Runoff_x-year $=$ Q_roof * A_roof

- A Iroof* SD Iroof* RVP Iroof

- A_Eroof*SD_Eroof $*$ RVP_Eroof

+ Q_gl * A_gl

+ P_x-year* A_LID

if Runoff_roof $<=0$, then:

$-1 . \overline{2} *$ S_LID *A_LID

Runoff_x-year $=\mathrm{Q} \_\mathrm{gl} *$ A_gl

$+\mathrm{P}_{-} \mathrm{x}$-year * A_LID

$-1.2 *$ S_LID * A_LID

Note:

- Based on the TR-55 calculation method, Initial Abstraction (I) is approximately equal to 0.2 multiplied by $\mathrm{S}(\mathrm{I}=0.2 * \mathrm{~S})$, the potential maximum retention after runoff begins. (USDA 1986) Therefore, the total maximum retention depth (I+S) is equal to $(0.2 * \mathrm{~S}+\mathrm{S}$ also stated as $(0.2+1) * \mathrm{~S}=1.2 * \mathrm{~S})$.

\section{Relationship Between the Two Calculation Processes}

The calculation method for the design storms with 2-, 5- and 10-year storm return periods and the above calculation method for the site runoff are based on the SCS-CN method, but there are differences. The differences between these calculation methods come from the different considerations of their conditions.

The calculation method for the daily runoff of the site considers the rain conditions of the site every day in a continuous climatic environment. The calculation of the runoff uses the TR-55 method, plus the HS method of the roof garden (Roehr and Kong, 2010).

However, the maximum storage capacity of the site is more significant in the calculation of the runoff of the storm event. Therefore, the green roof uses the retention volume of the growing medium itself instead of the evapotranspiration calculated by the HS method. In addition, in the LID system at grade, because rainwater will eventually be collected and stay in the LID system, the maximum storage capacity of the LID site is used instead of calculating the runoff directly using the TR-55 method.

\section{APPLICATION USE EXAMPLE}

Site Conditions 


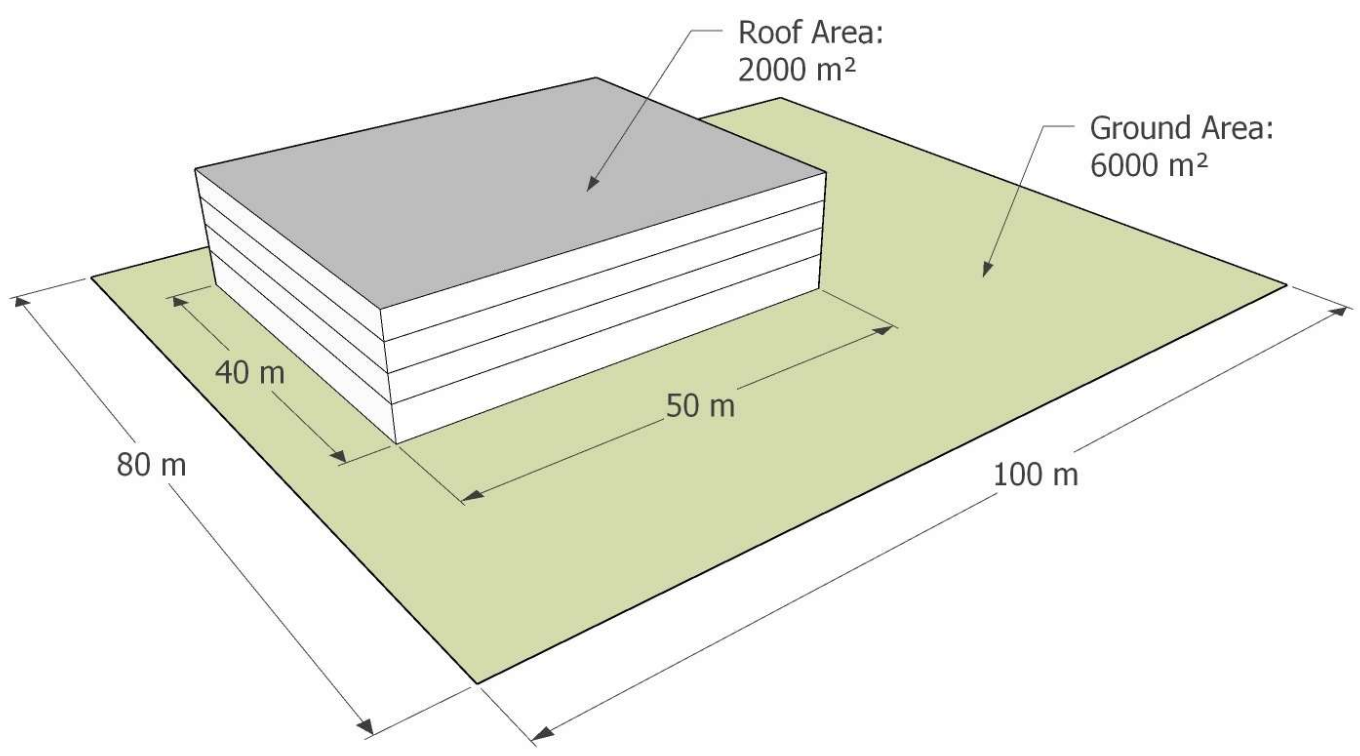

Figure 2 Example site conditions delineating site and building overall areas.

The site is located on the campus of University of British Columbia (UBC) in Vancouver, Canada, with a size of $100 \mathrm{~m}$ by $80 \mathrm{~m}$, see figure 2 . The existing building is $50 \mathrm{~m}$ by $40 \mathrm{~m}$ on the site and the site does not currently meet LID requirements and needs to be renovated. The LID application will be used to provide stormwater quantity data to decide which LID strategy should be used for the site's design upgrades.

\section{LID Application Workflow}

The workflow of the LID application needs to first develop LID goals (Figure 3). Then, by using the application to do all necessary calculations an LID strategy is developed that conforms to the LID goals for the preliminary site design in the next phase.

\section{Implementation}

\section{Step 1 - Develop LID Goals}

The principles of the LID goals are based on the goal of the Integrated Rainwater Management Plan of UBC's Okanagan Campus: diverting 100\% of rainwater from the municipal system through capture, re-use, infiltration and storage (Shkurhan, 2017). In addition to this, LID strategies of the site should take into account not only the impact of extreme storm events, but also the convenience of daily maintenance and landscape aesthetics of the site. 


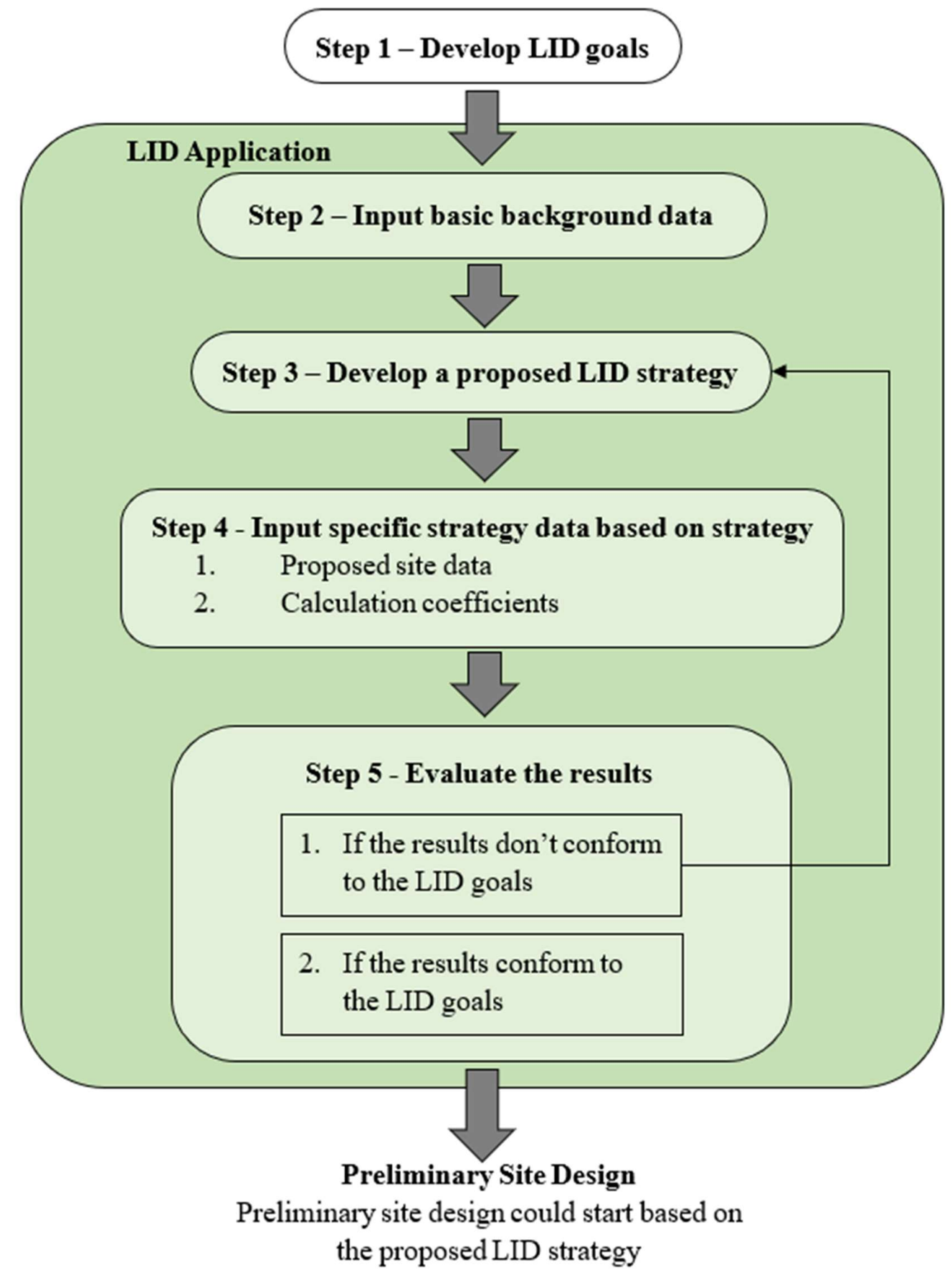

Figure 3 User workflow indicating the steps needed to fill out the Holistic Stormwater Runoff Management Application and achieve stormwater runoff results.

The specific LID goals are as follows:

1. The site can retain a 5 year design storm event.

2. The site can reduce $90 \%$ of annual runoff.

3. Because there is a $20 \mathrm{~m}^{3}$ water storage system in the existing building for the green roof irrigation, the total irrigation volume of the green roof during the dry season should not exceed $20 \mathrm{~m}^{3}$. 


\section{Step 2 - Input Basic Background Data}

To use the application, some basic information about weather, location and proposed site material needs to be inserted before obtaining results. Here are four types of data that are required:

1. Daily precipitation in a year

2. Daily high and low temperatures in a year

3. The latitude of the site

4. Storm event daily precipitation depth

The first two are obtained from airport weather stations which monitor hourly precipitation and temperature date. The latitude can be easily obtained by GPS or online. And the storm event data can be found in this case from the Environment and Climate Change Canada online open database.

Step 3 - Develop an LID Strategy

Strategy One: A large area of green roof will be used to reduce the amount of rainwater discharged into the site. According to the functional requirements of the building, at least $3000 \mathrm{~m}^{2}$ of ground area needs to be reserved as a concrete hardscape for students' activities. Considering other daily use of students, set aside more than $500 \mathrm{~m}^{2}$ as an open lawn, and the remaining area can be used as LID green space.

Step 4 - Input Strategy Data

Specific strategy data includes proposed site data and corresponding calculation coefficients. The data can be filled in the 'Site Data Input Section' in the application (Figure 4).

Proposed site data:

Proposed site data includes the total area of the site, the roofs, pervious pavement area, the area of the extensive and intensive green roof, the floor impervious pavement area, and the LID system area.

Calculation Coefficients:

It includes the $\mathrm{CN}$ value used in the $\mathrm{CN}$ Method calculation, and the Kc value used in the HS Method calculation. Based on the specific situation of the site, users could select the corresponding coefficients in the 'Help' tab in the application. All the site data used for strategy one is listed in Table 2.

Step 5 - Evaluating the Results

All results can be collected from the calculator shown in Figure 3. The collected results needing to be evaluated are in Table 3. 


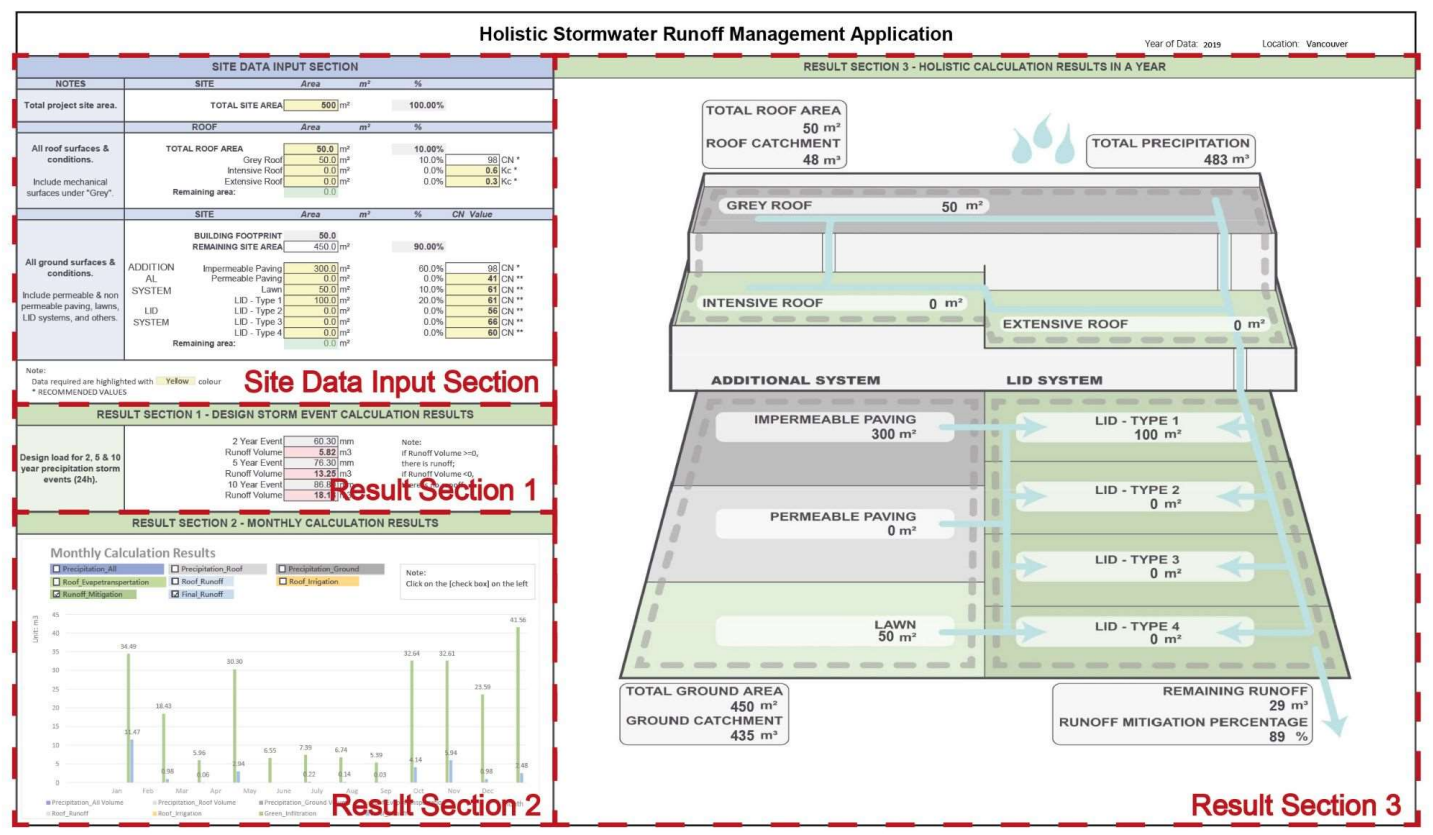

Figure 4 Calculator page of stormwater application. Use the Holistic Stormwater Runoff Management Application.

Table 2 Strategy one site data.

\begin{tabular}{|l|l|l|}
\hline Item & Area & Coefficient \\
\hline Grey Roof & $750 \mathrm{~m}^{3}$ & $\mathrm{CN}=98$ \\
\hline Intensive Roof & $1250 \mathrm{~m}^{3}$ & $\mathrm{Kc}=0.6$ \\
\hline Extensive Roof & $0 \mathrm{~m}^{3}$ & $\mathrm{Kc}=0.3$ \\
\hline Impermeable Paving & $3200 \mathrm{~m}^{3}$ & $\mathrm{CN}=98$ \\
\hline Lawn & $800 \mathrm{~m}^{3}$ & $\mathrm{CN}=61$ \\
\hline LID - Type 1 & $1000 \mathrm{~m}^{3}$ & $\mathrm{CN}=61$ \\
\hline LID - Type 2 & $1000 \mathrm{~m}^{3}$ & $\mathrm{CN}=56$ \\
\hline
\end{tabular}

Table 3 Strategy one results.

\begin{tabular}{|l|l|l|}
\hline Item & Result & Result Source \\
\hline 5 Year Period Runoff Volume & $-47.08 \mathrm{~m}^{3}$ & Result Section 1 \\
\hline Runoff Mitigation Percentage & $94 \%$ & Result Section 3 \\
\hline Total Roof Irrigation Volume & $166.18 \mathrm{~m}^{3}$ & Result Section 2 \\
\hline
\end{tabular}

From the table it can be seen that:

1. The site can withstand 5 year design storm events.

2. The site can retain more than $90 \%$ of the runoff.

3. The irrigation volume is much more than the $20 \mathrm{~m}^{3}$ goal set. 
Therefore, the strategy needs to be adjusted to reduce the irrigation volume. Steps one and two do not require changes, therefore we can jump ahead to step three and develop a new strategy to help obtain the project goals.

Step 3 - Developing a Different LID Strategy

Based on the result of strategy one, strategy two is as follows:

Some of the green roof area should be reduced to keep the total roof irrigation volume less than $20 \mathrm{~m}^{3}$. At least $3000 \mathrm{~m}^{2}$ of the ground area still needs to be reserved as a hard concrete space. As there is less green roof area, which will result in more runoff from the roof, the open lawn area can be appropriately reduced to increase the area of LID green space.

\section{Step 4 -Input New Strategy Data}

Table 4 Strategy two site data.

\begin{tabular}{|l|l|l|}
\hline Item & Area & Coefficient \\
\hline Grey Roof & $1350 \mathrm{~m}^{3}$ & $\mathrm{CN}=98$ \\
\hline Intensive Roof & $500 \mathrm{~m}^{3}$ & $\mathrm{Kc}=0.6$ \\
\hline Extensive Roof & $150 \mathrm{~m}^{3}$ & $\mathrm{Kc}=0.3$ \\
\hline Impermeable Paving & $3000 \mathrm{~m}^{3}$ & $\mathrm{CN}=98$ \\
\hline Lawn & $750 \mathrm{~m}^{3}$ & $\mathrm{CN}=61$ \\
\hline LID - Type 1 & $1000 \mathrm{~m}^{3}$ & $\mathrm{CN}=61$ \\
\hline LID - Type 2 & $1250 \mathrm{~m}^{3}$ & $\mathrm{CN}=56$ \\
\hline
\end{tabular}

Step 5 - Evaluate New Results

All results data needed for evaluation are collected in the table below.

Table 5 - Strategy two results.

\begin{tabular}{|l|l|l|}
\hline Item & Result & Result Source \\
\hline 5 Year Period Runoff Volume & $-35.10 \mathrm{~m}^{3}$ & Result Section 1 \\
\hline Runoff Mitigation percentage & $95 \%$ & Result Section 3 \\
\hline Total Roof Irrigation Volume & $15.71 \mathrm{~m}^{3}$ & Result Section 2 \\
\hline
\end{tabular}

Based on results from Table 5:

1. The site can withstand a 5 year design storm event.

2. The site can retain $90 \%$ of the runoff.

3. The irrigation volume is less than $20 \mathrm{~m}^{3}$. 
Since LID strategy two has reached all the goals, no further adjustment is needed. Therefore, the in-depth design can be carried out on the basis of the second LID strategy.

\section{DISCUSSION}

Throughout the development of the spreadsheets methodology the authors recognized the challenges when it comes to modelling green roofs and accurately accounting for water retention, evapotranspiration and the remaining roof runoff. As ET plays a key role in retaining stormwater on the roof, modelling ET was seen as a practical and necessary solution to reducing stormwater in a holistic design. There are many common ET calculation methods that have been developed for agricultural applications, however they are not always applicable to urban green roofs (DiGiovanni et al., 2013). While there are existing studies estimating the $\mathrm{CN}$ values of green roofs, utilizing the HS method is more appropriate as rainwater cannot infiltrate into green roofs as it traditionally would at ground level (Roehr and Kong 2010). The Penman equation with revised wind function and the FAO-56 PM performed best in Emily Voyde's research (Voyde, 2011). However due to lack of proper climatic data in many developing countries and the aim of making an easy-to-use LID application for global use, the simpler HS Method was used which requires only a few weather parameters to be input.

In addition to modelling ET, there are other factors that affect green roofs ability to retain rainwater which include growing media, roof slope and vegetation type. Among these factors, the growing media was believed to be the most significant (Akther et al., 2018). For growing media, media depth, and media composition which includes water retention fabric are the most important factor for water retention (Rowe et al., 2005). For soil or growing media, the various stages of water saturation include: completely dry, permanent wilting point, field capacity and full saturation (BC Ministry of Agriculture, 2015). 'Plant available water' (PAW), the water content in between the permanent wilting point and field capacity, is the water that can be used by plants. A variety of living roof media reported in the literature collected by Daniel Roehr and Elizabeth Fassman-Beck shows that the PAW amounts ranged from 10\% - 40\% while most of the PAW amounts are between 20\% - 30\% (Roehr and Fassman-Beck 2015). Additionally, Lars Bengtsson researched on an extensive roof and found that the PAW is $30 \%$ (Bengtsson, et al., 2004). Based on the Green Roof Guidelines from FLL (FLL 2018), the maximum water capacity, which is the water content in between completely dry to field capacity, should be $30 \%$ - $65 \%$ for intensive roof and 20\% - 65\% for extensive roof. (Lösken et al., 2018) The maximum water capacity is twice as much as PAW based on the comparison in Auckland (Roehr and Fassman-Beck, 2015). It means that the standard from the FLL is $15 \%-32.5 \%$ for intensive roofs and $10 \%-32.5 \%$ for extensive roofs. As a result, the average of the percentages, $23 \%$ for intensive roofs and $21 \%$ for extensive roofs, are used as the retention volume percentages for green roofs in this paper.

\section{CONCLUSIONS}

This application was developed to promote the design and planning of a holistic LID system at the initial stages of design; with the goal of reducing stormwater runoff, preventing urban 
flooding, and providing users a method for evaluating design decisions. By planning for LID at early design stages designers can better weigh the pros and cons of various systems as it relates to their building and site for more informed decisions when it comes to stormwater management. By providing the following features this application becomes a powerful asset to users looking to evaluate stormwater management at the schematic level of design:

- Application is based on locally sourced weather data generated by all weather stations/airports, so it is globally applicable and ready for yearly updates.

- A user-friendly interface with a low threshold of understanding needed to generate stormwater estimates.

- Graphic component to help users visualize the spaces they are designing and the flow of stormwater through the site.

- Non-goal oriented, giving the user a flexible design process, they can tailor to their project/design needs.

- Holistically focused so all precipitation generated on site is considered and can be factored into the project and design needs.

- Yearly rainfall and storm events are simultaneously generated so users can maximize LID capabilities based on site context and weather data.

- Lower the threshold of understanding for mathematical calculations being used to generate results, allowing for a larger user base not limited to stormwater design professionals.

This application was developed to help designers plan for LID at the early stages of design, where effective planning can make all the difference in a project's success. The authors recognize many of the existing tools used to determine LID require access to specialized data or knowledge held by specific professionals. Therefore, it was important when developing this application that not only was the tool useful and user-friendly to a variety of users but that it could have a global impact introducing LID, utilizing local weather data and design conditions. It is recognized that there are challenges with this methodology, and it is still in development. The authors intend to continue the development of this application, taking it from the excel based calculation to a website for a wider user base and additional testing for accuracy and effectiveness. It was out of the scope of this paper to cross examine the developed application with existing tools (Table 1), however the authors recognize the importance of this and intend to compare and analyze existing applications against their own.

In summary, the application and methodology proposed in this paper is viewed as a critical and necessary LID exploration method in the planning process of urban LID implementation. By planning for LID systems at the initial stages of design the ecological and stormwater management benefits LID has to offer can be maximized. This method provides the technical support designers need to balance building and site development with environmental needs; helping form overall design goals while providing the users visual volumetric data on the impact their site design has on stormwater management. 


\section{ACKNOWLEDGEMENTS}

We would like to thank Kevin Kong and Jon Laurenz for their professional advice and support throughout the many drafts and revisions of this paper.

\section{LITERATURE CITED}

Akinyemi, E. 2008. "International experiences with low impact development (LID)." Paper presented at: International Low Impact Development Conference: Low Impact Development for Urban Ecosystem and Habitat Protection. https://doi.org/10.1061/41009(333)66

Akther, M, J. He, A. Chu, J. Huang, and B. van Duin. 2018. "A review of green roof applications for managing urban stormwater in different climatic zones." Sustainability 10(8): 2864. https://doi.org/10.3390/su10082864.

Allen, V., T. Walker, and T. Schemper. 2010. "Development and application of modular LID site planning tool." Paper presented at: International Low Impact Development Conference: Low Impact Development. https://doi.org/10.1061/41099(367)63

Asiedu, J.B. 2020. "Reviewing the argument on floods in urban areas: a look at the causes." Theoretical and Empirical Researches in Urban Management 15(1): 24-41.

BC Ministry of Agriculture. 2015. "Soil Water Storage Capacity and Available Soil Moisture." Order No. 619.000-1. https://www.droughtmanagement.info/literature/BC_MA_Soil_Water_Storage_Capacity_200 $\underline{5 . p d f}$

Bengtsson, L., L. Grahn, and J. Olsson. 2004. "Hydrological function of a thin extensive green roof in southern Sweden.” Hydrology Research 36(3): 259-68. https://doi.org/10.2166/nh.2005.0019.

Carter, T., and C. Rhett Jackson. 2007. "Vegetated roofs for stormwater management at multiple spatial scales." Landscape and Urban Planning 80(1-2): 84-94. https://doi.org/10.1016/j.landurbplan.2006.06.005.

Chang, H. and J. Franczyk. 2008. "Climate change, land-sse change, and floods: toward an integrated assessment." Geography Compass 2(5): 1549-79. https://doi.org/10.1111/j.1749$\underline{8198.2008 .00136 . x}$

Chang, N. 2010. "Hydrological connections between low-impact development watershed best management practices and sustainable development" Journal of Hydrologic Engineering 15(6) 384-385. https://doi.org/10.1061/(ASCE)HE.1943-5584.0000236

Cheng, M., L.S. Coffman and M.L. Clar. 2001. "Low-impact development hydrologic analysis" Paper presented at: Specialty Symposium on Urban Drainage Modeling at the World Water and Environmental Resources Congress. https://ascelibrary.org/doi/10.1061/40583\%28275\%2963

Chin, D.A. 2019. "Estimating peak runoff rates using the rational method." Journal of Irrigation and Drainage Engineering 145(6): 040190061-8. https://doi.org/10.1061/(asce)ir.1943$\underline{4774.0001387}$

Crnogorac, C. and V. Rajcevic. 2018. "Climate change and protection against floods." Climate Change Management Climate Change Adaptation in Eastern Europe 127-36.

DiGiovanni, K., S. Gaffin, F. Montalto, and C. Rosenzweig. 2011. "The applicability of classical predictive equations for the estimation of evapotranspiration from urban green spaces: green roof results." Paper presented at: World Environmental and Water Resources Congress. https://doi.org/10.1061/41173(414)80.

"EPA National Stormwater Calculator." Environmental Protection Agency (EPA), December 10, 2019. https://swcweb.epa.gov/stormwatercalculator/

Eckart, K., Z. McPhee and T. Bolisetti. 2017 "Performance and implementation of low impact development - a review" Science of the Total Environment 607-608: 413-32. https://doi.org/10.1016/j.scitotenv.2017.06.254.

FLL 2018. Guidelines for the Planning, Construction and Maintenance of Green Roofs. Landscape Development and Landscaping Research Society, Bonn. 
Gilland, T. 2002. Nature's Revenge?: Hurricanes, Floods and Climate Change. Hodder \& Stoughton. London.

Guillette, A. 2016. "Low impact development technologies." Whole Building Design Guide, National Institute of Building Sciences, March 11, 2016. https://www.wbdg.org/resources/low-impactdevelopment-technologies

Hayes, D.C., and R.L. Young. 2006. "Comparison of peak discharge and runoff characteristic estimates from the rational method to field observations for small basins in central Virginia." United States Geological Survey (USGS) Scientific Investigations Report 2005-5254. https://doi.org/10.3133/sir20055254.

Hluštík, P., M. Úterský, V. Václavík and T. Dvorský. 2016. "Use of the program SWMM to simulate rainfall runoff from urbanized areas. "Proceedings of the 2nd International Conference on Engineering Sciences and Technologies: Advances and Trends in Engineering Sciences and Technologies II. https://doi.org/10.1201/9781315393827-72.

Hunt, W.F., R. Traver, A.P. Davis, C.H. Emerson, K.A. Colins and J.H. Stagge. 2010. "Low impact development practices: designing to infiltrate in urban environments." Chapter 12 In: N. Chang (Editor), Effects of Urbanization on Groundwater: An Engineering Case-Based Approach for Sustainable Development. American Society of Civil Engineers. https://doi.org/10.1061/9780784410783.ch12

“LEED v4.1.” U.S. Green Building Council, April 2, 2021. https://www.usgbc.org/leed/v41.

"Living Building Challenge." International Living Future Institute, June 2019. https://livingfuture.org/lbc/.

Li, Q., F. Wang, Y. Yu, Z. Huang, M. Li and Y. Guan. 2018. "Comprehensive performance evaluation of LID practices for the sponge city construction: a case study in Guangxi, China." Journal of Environmental Management 231: 10-20. https://doi.org/10.1016/j.jenvman.2018.10.024.

Li, X.i, F. Zhou, D. Healy, and K. Robinson. 2015. "Development of low impact development design guide." Presented at: 2011 Low Impact Development Conference: Low Impact Development Technology: Design Methods and Case Studies. https://doi.org/10.1061/9780784413883.014.

McCormick, B.C. and K.N. Eshleman. 2011. "Assessing hydrologic change in surface-mined watersheds using the curve number method." Journal of Hydrologic Engineering 16(7): 575 84. https://doi.org/10.1061/(asce)he.1943-5584.0000344.

McMahon, P.L., C.L. Sorhaindo and W.K. Barry. 2018. "Analysis of low impact development using continuous simulation hydrologic modeling." Paper presented at: The International Low Impact Development Conference. https://doi.org/10.1061/9780784481783.013.

Mishra S.K. and V.P Singh. 2003. "SCS-CN Method." In: Soil Conservation Service Curve Number (SCS-CN) Methodology. Water Science and Technology Library, vol 42. Springer, Dordrecht.

Olorunkiya, J., E. Fassman and S. Wilkinson. 2012. "Risk: a fundamental barrier to the implementation of low impact design infrastructure for urban stormwater control." Journal of Sustainable Development 5(9): 27-41. https://doi.org/10.5539/jsd.v5n9p27

Pate, Megan. 2019. "Engineering Design Manual." Vancouver: City of Vancouver Engineering. https://vancouver.ca/files/cov/engineering-design-manual.PDF

Pennington, M. 2012. "The rational method - frequently used, often misused." Paper presented at: Water New Zealand Stormwater Conference. https://www.waternz.org.nz/Attachment?Action=Download\&Attachment id=846

Ports, M.A. 2001. "Evaluation of urban runoff control programs." Paper presented at: Third International Conference on Watershed Management: Watershed Management. https://doi.org/10.1061/40706(266)5

Prickett, L. and J. Bicknell. 2010. "LID, LEED, and alternative rating systems - integrating low impact development techniques with green building design." Presented at: The Low Impact Development International Conference: Low Impact Development https://doi.org/10.1061/41099(367)70 
Rodak, C.M., T.L. Moore, R. David, A.D. Jayakaran and J.R. Vogel. "Urban stormwater characterization, control, and treatment." Water Environment Research 92: 1552-1586. https://doi.org/10.1002/wer.1403

Roehr, D. and E. Fassman-Beck. 2015. Living Roofs in Integrated Urban Water Systems. Taylor \& Francis Group. London: Routledge.

Roehr, D. and K. Yuewei. 2010. "Runoff reduction effects of green roofs in Vancouver, BC, Kelowna, BC, and Shanghai, P.R. China." Canadian Water Resources Journal 35(1): 53-68. https://doi.org/10.4296/cwrj3501053

Roehr, D., J. Laurenz and Y. Kong. 2008. "Green envelopes: contribution of green roofs, green facades, and green streets to reducing stormwater runoff, $\mathrm{CO}^{2}$ emissions, and energy demand in cities." Paper presented at: International Low Impact Development Conference: Low Impact Development for Urban Ecosystem and Habitat Protection. https://doi.org/10.1061/41009(333)13

Rossman, L.A., R.E. Dickinson, T. Schade, C.C. Chan, E. Burgess, D. Sullivan and F. Lai. 2004. "SWMM 5 - the next generation of EPA's storm water management model." Journal of Water Management Modeling. https://doi.org/10.14796/jwmm.r220-16

Samani, Z. 2000. "Estimating solar radiation and evapotranspiration using minimum climatological data." Journal of Irrigation and Drainage Engineering 126(4): 265-67. https://doi.org/10.1061/(ASCE)0733-9437(2000)126:4(265)

Sharma, A., T. Gardner and D. Begbie. 2019. Approaches to Water Sensitive Urban Design: Potential, Design, Ecological Health, Urban Greening, Economics, Policies, and Community Perceptions. Amsterdam, Netherlands: Elsevier.

Shkurhan, G., 2017. Integrated Rainwater Management Plan. Kelowna, BC: Urban Systems Ltd.

Snyder, R.L. and S. Eching. 2002. Penman-Monteith Daily (24-Hour) Reference Evapotranspiration Equations for Estimating ETo, ETr and HS ETo with Daily Data. Sacramento, CA: University of California.

"Stormwater Presumptive Approach Calculator." BES Stormwater PAC. City of Portland Oregon, April 2020. https://www.portlandoregon.gov/bes/pac/

"Stormwater Management Calculator." Green Values Stormwater Management Calculator. Center for Neighborhood Technology (CNT), 2020. https://greenvalues.cnt.org/\#calculate.

"Storm Water Management Model (SWMM)." EPA. Environmental Protection Agency, August 24, 2020. https://www.epa.gov/water-research/storm-water-management-model-swmm

"Storm Water Management Model Reference Manual Volume II Hydraulics." EPA. Environmental Protection Agency, 2017. https://nepis.epa.gov/Exe/ZyPURL.cgi?Dockey=P100S9AS.TXT

"SWMM Modeling Methods for Simulating Green Infrastructure at a Suburban Headwatershed: User's Guide." EPA. Environmental Protection Agency, 2017. https://nepis.epa.gov/Exe/ZyPURL.cgi?Dockey=P100TJ39.txt

“Terminology of Low Impact Development” EPA. Environmental Protection Agency, 2012. https://www.epa.gov/sites/production/files/2015-09/documents/bbfs2terms.pdf

University of Minnesota Extension. "Basics of Irrigation Scheduling." Accessed December 10, 2020. https://extension.umn.edu/irrigation/basics-irrigation-scheduling

"U.S. Climate Resilience Toolkit.” Precipitation Frequency Data Server (PFDS) | U.S. Climate Resilience Toolkit. National Oceanic and Atmospheric Administration, April 22, 2021. https://toolkit.climate.gov/tool/precipitation-frequency-data-server-pfds.

US. Department of Agriculture (USDA), Soil Conservation Service (SCS). 1986. Urban Hydrology for Small Watersheds (TR-55 Revised). Washington, D.C.

VanWoert, N., D. Rowe, J. Andresen, C. Rugh, R. Fernandez, and L. Xiao. 2005. "Green roof stormwater retention." Journal of Environmental Quality 34(3): 1036-44. https://doi.org/10.2134/jeq2004.0364.

Voyde, E., 2011. "Quantifying the complete hydrologic budget for an extensive living roof." Dissertation, Department of Civil and Environmental Engineering

Wang, S. and W. Heng. 2018 "Extending the rational method for assessing and developing sustainable urban drainage systems." Water Research 144: 112-15. https://doi.org/10.1016/j.watres.2018.07.022. 